\title{
The Structure of an Afrikaans Collocation and Phrase Dictionary
}

\author{
Anna Nel Otto, Department of Afrikaans, \\ Vista University, Port Elizabeth, South Africa
}

\begin{abstract}
In this article an Afrikaans collocation and phrase dictionary for mother-tongue speakers (primary target group) as well as advanced learners (secondary target group) is discussed. The position which such a dictionary occupies among other dictionary types is pointed out. A motivation is also given for the inclusion of idioms and other fixed phrases in the proposed dictionary. The three key approaches with regard to the interpretation of the term collocation are examined, i.e. the text-oriented approach of Halliday and Hasan (1976), the statistically-oriented approach of Sinclair (Collins Cobuild) and the significance-oriented approach of Hausmann (1984). The arguments in this article favour Benson et al.'s (1986) implementation of the significance-oriented approach. Statistical evidence could be used to examine the usage frequency of collocations and phrases. The advantages and/or disadvantages of these approaches are considered. Three types of words and their treatment in the dictionary are discussed: those which have a very wide range of combination, those which have selectional restrictions imposed by general semantic features, and those of which the range of combination is restricted by certain other words. It is argued that only the last two types should be included in this dictionary. As one of the target groups is unsophisticated leamers with a limited grammatical background, the ideal would be to enter lexical collocations both at their bases and at the collocators. To save space however, more information such as examples could then be provided at the bases only. Grammatical collocations should be entered at the bases, i.e. nouns, verbs and adjectives. The division of the dictionary articles into two components to meet the needs of both intended target groups, is discussed.
\end{abstract}

Keywords: LEXICOGRAPHY, COLLOCATION DICTIONARY, LEXICAL COLLOCATIONS, GRAMMATICAL COLLOCATIONS, TRANSITIONAL COLLOCATIONS, IDIOMS, FREE COMBINATION, PROTOTYPE, SELECTIONAL RESTRICTIONS, BASE, COLLOCATOR

\section{Opsomming: Die struktuur van 'n Afrikaanse kollokasie- en frasewoorde-}

boek. In hierdie artikel word 'n Afrikaanse kollokasie- en frasewoordeboek vir sowel moedertaalsprekers (primêre teikengroep) as gevorderde aanleerders (sekondère teikengroep) beskryf. Die plek wat so 'n woordeboek inneem naas ander woordeboektipes word uitgewys. 'n Motivering word ook gegee vir die insluiting van idiome en ander vaste uitdrukkings in die voorgestelde woordeboek. Die drie hoofbenaderings met betrekking tot die interpretasie van die term kollokasie word ondersoek, d.i. die teks-georiënteerde benadering van Halliday en Hasan (1976), die statisties-georiënteerde benadering van Sinclair (Collins Cobuild) en die betekenis-georiënteerde bena-

* An earlier version of this article was presented at the Second International Conference of the African Association for Lexicography, held at the University of Natal, Durban, 14-16 July 1997. 
dering van Hausmann (1984). Die voor- en nadele van hierdie benaderings word oorweeg. Die argumente in đié artikel gee voorkeur aan Benson et al. (1986) se toepassing van đie betekenis. georiënteerde benadering. Statistiese gegewens sou gebruik kon word om die gebruiksfrekwensies van kollokasies en frases te ondersoek. Drie tipes woorde en hul hantering in die woordeboek word bespreek: diê wat met 'n baie wye reeks woorde kan verbind, dié waarvan đie seleksie beperk word deur algemene semantiese kenmerke en dié wat slegs met sekere ander woorde kan verbind. Daar word geargumenteer dat net laasgenoemde twee tipes in dié woordeboek opgeneem word. Aangesien een van die teikengroepe ongesofistikeerde aanleerders met 'n beperkte grammatiese kennis is, is die ideaal dat leksikale kollokasies sowel by hul basisse as by die kollokators opgeneem word. Om ruimte te bespaar, kan meer inligting soos voorbeelde dan slegs by die basisse verskaf word. Grammatiese kollokasies behoort by die basisse, d.i. selfstandige naamwoorde, werkwoorde en adjektiewe, opgeneem te word. Die verdeling van die woordeboekartikels in twee komponente om in die behoeftes van al twee die bedoelde teikengroepe te voorsien, word bespreek.

Sleutelwoorde: LEKSIKOGRAFIE, KOLLOKASIEWOORDEBOEK, LEKSIKALE KOLLOKASIES, GRAMMATIESE KOLLOKASIES, OORGANGSKOLLOKASIES, IDIOME, VRYE KOMBINASIE, PROTOTIPE, SELEKSIEBEPERKINGS, BASIS, KOLLOKATOR

\section{Introduction}

Knowles (1997: 72) says: "It is a well-known but regrettable fact that very, very few language communities possess satisfactory collocations dictionaries ... The normal unavailability of collocations dictionaries is a great pity because that is exactly what advanced learners need, and indeed, what many native speakers hanker after too. In fact, it is not stretching things too far to say that first-class collocational control is the hallmark of the true L2 expert; collocational control is, of course, normally the last linguistic subsystem to be mastered by L2 learners who proceed to an advanced level."

Where some languages have several collocation dictionaries, Afrikaans has none. Several Afrikaans phrase dictionaries do however exist. In this article an Afrikaans collocation and phrase dictionary, which is presently being compiled, is discussed.

\section{The place of the collocation dictionary among other dictionary types}

According to Hausmann et al. (1989: XLII, XLIII) one can, in theory, differentiate between the following major syntagmatic dictionaries: the dictionary of syntactic patterns, the dictionary of collocations, the dictionary of set expressions and idioms, the dictionary of proverbs, the dictionary of quotations and the sentential dictionary. In practice, however, it is often difficult for the lexicographer to decide whether a certain word combination is a collocation or an idiom since certain collocations contain semantic specialized constituents. Cowie (1981: 230) comments in this regard: "Restricted collocations and idioms 
are sufficiently related in terms of specialization of sense (of the part in the one case, of the whole in the other)." As the difference between collocations and idioms in this particular case is merely one of degree, this type of collocation can, within the cognitive approach, be regarded as nonprototypical idioms. Compare the following examples from Carstens (1992: 4): flou verskonings, vuil grappe, 'n koue blik, onverteerde feite. Benson (1989) uses the term "transitional collocation" for this category. If the lexicographer experiences problems with these distinctions, how can he/she expect the user to know whether one should look up a certain word combination in a collocation dictionary or in an idiom dictionary? This does not suggest that there is no need for separate dictionaries with regard to certain target groups - compare Benson (1989: 5) who believes that idioms should be entered in idiom dictionaries and important idioms in general-purpose dictionaries. According to him transitional collocations and technical collocations should be entered in collocation dictionaries. He (1990: 25-31) also maintains that our existing monolingual dictionaries should change and suggests the development of two types of monolingual dictionaries. The first is a monolingual decoding dictionary (MDD) that would include the largest possible number of "difficult" words and that would devote minimum space to collocations and the core vocabulary of a language. The second is a monolingual general-purpose dictionary (MGPD), intended for native speakers and learners who seek help with decoding and encoding language. "The learner who does not wish to use a learners' dictionary would find the MGPD ideal," Benson (1990: 27-28) argues. "Its decoding capability would be considerable, but, of course, would be less than that of the MDD. The encoding capability of the MGPD would be very strong, but it still could not compete with a specialized combinatory dictionary as a handbook for the production of texts." Every dictionary is written within a specific time and social framework for a specific target group. One could specifically compile a practical collocation dictionary (primarily) for advanced learners of Afrikaans (cf. Hausmann 1979, 1985), but which also contains the most frequently-used idioms and other fixed phrases or a theory-oriented collocation dictionary (containing only collocations) for linguists, language practitioners and lexicographers (cf. Mel'cuk and Žolkovskij 1984: 43, 73). A third option was chosen for the dictionary which is presently being compiled. The dictionary will contain collocations and phrases and will be directed not only at mother-tongue speakers as primary target group but also at advanced learners as secondary target group.

\section{The meaning of the term collocation}

The term collocation should however first be defined, since it gives rise to different interpretations.

For Firth (1957) collocation refers to a co-occurrence relation between individual lexical items, such as for example dark night and you silly ass. A certain 
vagueness in the use of the term by Firth has given rise to a number of different interpretations, which can prototypically be identified as three key standpoints (cf. Herbst 1996: 380), namely

(a) a text-oriented approach (cf. Halliday and Hasan 1976),

(b) a statistically-oriented approach (cf. the Cobuild Project of Sinclair) and

(c) a significance-oriented approach (cf. Hausmann 1984: 398).

Herbst (1996: 380) evaluates the different approaches to collocation and comes to the following conclusions.

The text-oriented approach to collocation amounts to not much more than saying that in a text about coastal walking there is a certain likelihood for words such as coast, sea, path, climb or steep to occur as well. This kind of likelihood of co-occurrence of lexical items, however, seems to be determined to a greater degree by extralinguistic than by linguistic factors. The interpretation of collocation employed by Halliday and Hasan can probably be ignored. Hasan herself has shown that the usefulness of such an approach is limited (Herbst 1996: 383). It must also be doubted whether there is much point in using collocation for any kind of co-occurrence of two lexical items.

A purely statistical view of collocation as advocated by Sinclair seems problematical for a number of reasons. Firstly, there are the general problems involved in any kind of corpus analysis, especially regarding the representative nature of the material analysed. However, computer-assisted analysis may help overcome this problem. In this regard Smadja (1993) also suggests that a computer could be used to get a representative database. He points out that several approaches have been proposed to retrieve various types of collocations from the analysis of large samples of textual data. These techniques automatically produce large numbers of collocations along with statistical figures that reflect the relevance of the associations. None of these techniques provides functional information along with the collocations. Also, the results produced often contain improper word associations, i.e. not true collocations. Smadja (1993: 143-177) describes a set of techniques based on statistical methods for retrieving and identifying collocations from large textual corpora. These techniques produce a wide range of collocations and are based on some original filtering methods that allow the production of richer and higher-precision output. These techniques resulted in a lexicographical tool, Xtract. A lexicographical evaluation of Xtract shows that $80 \%$ of the identified collocations are correct. Church and Hanks (1990) and Church et al. (1991) emphasize the importance of human judgement used in conjunction with these tools. For the proposed dictionary the compiler's own database containing data (mainly from Afrikaans magazines) as well as the database of the publishers will be used.

The second problem that Herbst (1996: 383) points out with regard to a purely statistical view of collocation is that positional statements such as those produced by Sinclair (in Cobuild) are of limited value if one disregards the con- 
text. Greenbaum (1974/1988: 115) illustrated, for example, that the occurrence of particular adverbs is determined by a number of factors. It must be doubted whether a purely statistical kind of analysis is able to accommodate the complexity of such factors.

Finally, there is the problem of the limited power of statistical statements. Is dark night for instance a significant collocation because nights tend to be dark and not bright?

The significance-oriented approach makes provision for gradience. Any attempt to define collocation in this narrow sense can thus only be aiming at defining a kind of prototype of collocation, by recognizing the gradience character of the distinction between collocations and free combinations on the one hand and between collocations and idioms on the other hand.

\section{The macrostructure of the proposed dictionary}

For the proposed dictionary on collocations and phrases the compiler decided to focus not only on the lexical and grammatical collocations as used by Benson et al. (1986), but also on semantic collocations.

There are words which have a very wide range, others where the selectional restrictions can be described through general semantic features, and words of which the range is restricted to certain other words. Svensen (1993: 102) uses the term semantic collocations for the second type of words.

The Afrikaans verb aanvaar (accept) can for example co-occur with the following nouns: aanbod, argument, besluit, benoeming, beroep, betrekking, erfenis, gevolge, geskenk, gesag, hulp, jou lot, mosie, nederlaag, ooreenkoms, pos, resolusie, slagspreuk, siekte, uitdaging, skenking, uitnodiging, uitspraak, verantwoordelikheid, voorstel, wet, die bevel oor die regiment, ultimatum, die laste van die lewe, teenslae, smart, pyn ...

The question arises: Should one include words like aanvaar which have a fairly wide range and if so, how should one treat this particular type of collocation?

The following options could be considered:

(1) one does not include collocations of this type,

(2) one includes the collocations just as one finds them in the data collection, or

(3) one includes the collocations and uses a system where one indicates that certain words act as hyponyms and/or one uses selectional restrictions where possible.

As regards option (1), these collocations should be included for a number of reasons:

(a) We live in a multilingual country where a large percentage of the people who speak Afrikaans, are not mother-tongue speakers of Afrikaans. 
(b) Collocations are usually not directly translatable, e.g.

aanvaar bevel oor iemand/verantwoordelikheid - assume command/ control/responsibility

aanvaar erfenis - enter upon inheritance

aanvaar pos - accept position

aanvaar aanbod/hulp - take up, accept offer/help

aanvaar die gevolge (van jou dade) - face (the consequences)

aanvaar nederlaag - take (a defeat)

aanvaar aanname, argument, besluit, dokument, mosie, oreenkoms, resolusie, uitspraak, voorstel, ens. - accept

aanvaar jou lot, die laste van die lewe, siekte, pyn, smart, teenslae come to terms with

(c) Sometimes a verb has a synonym or synonyms, but one cannot use the synonym or synonyms in all contexts in the place of this verb, cf. aanvaar and aanneem:

\section{bevel aanvaar $/ *$ aanneem \\ verantwoordelikheid aanvaar/*aanneem pos aanvaar/*aanneem aanbod/hulp/raad anvaar // aanbod/hulp/raad aanneem aanvaar die gevolge van jou dade/*aanneem aanvaar nederlaag/*aanneem aanvaar jou lot/pyn/smart, ens. /*aanneem}

With regard to the use of synonyms mention should be made of a small part of the research that was conducted with 20 first-year students. Sixteen students had Xhosa as their mother tongue and Afrikaans as their third language. Three students had English as mother tongue and only one had Afrikaans as mother tongue.

The students had to choose between the two synonyms behaal and bereik in five sentences:

(1) Ek het die dorpie teen sononder (behaal, bereik).

(2) Sy het 'n oorwinning (behaal, bereik) oor haar teenstander.

(3) Ek is so bly dat ek my doel (behaal, bereik) het.

(4) Sy het groot sukses (behaal, bereik) met die kweek van hierdie rose.

(5) Hy het nou die hoogste sport in sy loopbaan (behaal, bereik).

In sentence (1) 15 students chose the correct synonym, i.e. bereik, and 5 students chose the wrong one. In sentence (2) 14 students chose the correct synonym, i.e. behaal, and 6 students chose the wrong word. In sentence (3) 13 students chose the correct word, i.e. bereik, and 7 students chose the wrong word. 
(Of course behaal 'n doel is possible in Afrikaans, but then it is used in the context of sport.) In sentence (4) 14 students chose the correct word, i.e. behaal, while 6 chose the wrong one. In sentence (5) 10 students chose the correct word, i.e. bereik, and 10 students the wrong one.

Although bereik can combine with a wide range of words, one can therefore argue that one should include both bereik and behaal in the dictionary and have cross-references between them to help the user to choose the right word.

(d) Another motivation for including collocations is that one can present antonyms, again by using cross-referencing, e.g. aanbod/uitnodiging aanvaar/van die hand wys vs. argument aanvaar/verwerp, etc.

With regard to option (2), one could not consider this option because it implies that no other collocates exist other than those listed in the dictionary, which is not true. Compare the following sentence with aanvaar: "Die vooruitsig op 'n bleskop aanvaar Cora Marie (a cancer patient) nou gelate." One of the meaning distinctions of aanvaar could be: "berus in" (come to terms with) with the selection restriction "iets MOEILIKS of NEGATIEFS", followed by the most frequently used collocations. Therefore, one should include collocations with a wide range, provided that one combines this option with option (3): to use selection restrictions and/or hyponyms. An example of a hyponym could be verantwoordelikheid aanvaar which could then be replaced by e.g. pligte, toesig, etc.

One should, however, be very careful when deciding on the wording of selection restrictions. Carstens (1992: 4) states for instance that the verb pleeg (commit) is only selected in the presence of the meaning feature [+MISDAAD]/[+CRIME]. One does not however use pleeg only in the presence of the meaning characteristic [+MISDAAD], cf. Ek het ook 'n paar versies ('n skildery) gepleeg (HAT: 803). Furthermore, pleeg is not often used in combination with words indicating crime. Compare:

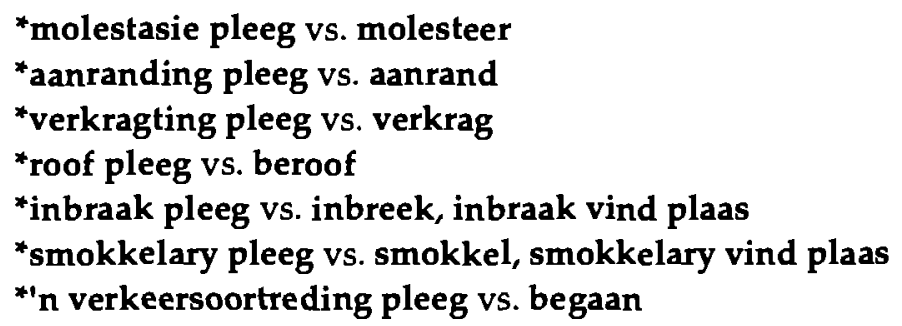

A third category of collocations includes words of which the range is restricted by other words, e.g. dawerende applous, die onderspit delf, etc. 


\section{Where should collocations be entered in the dictionary?}

\section{Hausmann's approach}

Hausmann breaks down lexical collocations into a base and a collocator (1985: 119-121). In verb + noun collocations such as brand stig the noun is the base, and the verb is the collocator. In adjective + noun collocations such as dawerende applous the noun is once again the base, and the adjective is the collocator. In adverb + verb collocations such as haarfyn beskryf the verb is the base, and the adverb is the collocator. In adverb + adjective collocations such as blakend gesond the adjective is the base, and the adverb is the collocator.

In theory this works well with sophisticated learners who know the difference between the different parts of speech. However, apart from the fact that most users do not read the front matter of dictionaries, many learners struggle with parts of speech and even if they know the difference between for example a noun and a verb in theory, they sometimes do not know whether an individual word is a noun or a verb because they do not know the meaning of the particular word. For unsophisticated learners with a limited grammatical background, the ideal would be to have these collocations entered both at the base and the collocator. To save space however, more information, such as examples could perhaps be providepd only at the bases.

Hausmann does not refer to grammatical collocations. However, on the basis of his approach we can, following Benson (1986: 6), assume that:

(a) if a grammatical collocation contains a noun, the noun is the base - vertroue in, neem 'n eed dat hy dit sal doen, plesier om te werk, op jou stukke/ gemak;

(b) if a grammatical collocation contains an adjective, the adjective is the base - oortuig dat, geheg aan;

(c) if a grammatical collocation consists of a verb and a preposition, the verb is the base - dink aan, iemand herinner aan, jou vergryp aan;

(d) if a grammatical collocation consists of a verb and a second verb in the infinitive, the first verb is the base - besluit om iets te doen, geniet om iets te doen.

\section{The microstructure of the proposed dictionary}

The dictionary article will be divided into two interactive components.

\section{The first component}

In the first component combinations will be placed under the different polysemous senses of the lemma (i.e. the base of the combination) without examples. In the case of collocations no definitions will be provided since collocations are 
by definition transparent constructions (cf. Gouws 1989: 232).

Transitional collocations and idioms will however be provided with definitions, and labels will be used to indicate nonstandard forms.

Fixed expressions where the lexical base does not semantically relate to any of the listed senses of the corresponding lemma, will be included under a separate expression component.

Polysemous senses will be ordered according to parts of speech. The primary model which will be followed is the BBI Dictionary of English Word Combinations.

\section{The second component}

The lack of adequate examples and the unusual nature of some of the examples in the existing Afrikaans standard dictionaries are often pointed out by dictionary reviewers and metalexicographers (cf. Lombard 1992: 148-164). In this dictionary the current situation will be rectified. In the second component, typographically distinguished from the first, there will be an example for every combination mentioned in the first component. This will have an encoding function, especially for the secondary target group. Sentences from spoken and written Afrikaans will reflect real Afrikaans as it is currently used. The ideal will therefore be to use as many citations as possible; however, verbal illustrations will be used when the need arises to illustrate more than one information type in the same sentence (cf. Gouws 1989: 233). There will be a direct relation between the examples in the second component and the labels used in the first component.

The arrangement of combinations in the first component of the article will most probably require that the potential users should use their linguistic intuition; a strict alphabetical arrangement (by using secondary keywords) of examples in the second component should make lighter demands on the dictionary reference skills of the secondary users, for whom this component is especially intended.

A preliminary example is provided below:

kaf $\mathbf{n}$ 1. [OMHULSELS, DOPPE] * 'n baal/hoop kaf; gebaalde/ongebaalde kaf; fyn/growwe kaf; stoppels kaf. - die kaf van die koring/korrels/koringkorrels skei; die kaf uit die koring wan. 2. [ONSIN, BOG] • $n$ klomp/spul kaf; blote/louter(e)/pure kaf. kaf praat/kwytraak/verkoop/skryf/publiseer; nie/geen/g'n kaf duld nie; nie/geen g'n kaf vat nie (informeel); deur die kaf sny; iets as kaf afmaak. die kaf en/van die koring/korrels skei, die koring/korrels en/van die kaf skei, tussen die kaf en (die) koring/korrels onderskei, tussen die koring/korrels en (die) kaf onderskei [DIE GOEIE/WAARDEVOLLE VAN DIE SLEGTE/WAARDELOSE SKEI].

The following is part of the data on which the above article is based: 
Die oudstaatspresident het ' $n$ uiteensetting van sy aandeel in die hervomingsproses gegee wat selfs sy felste kritici nie sonder meer as kaf kan afmaak nie. 0 Sowat 3000 bale kaf is in die brand verwoes. $0 \mathrm{Om}$... as 'n oplossing vir die uiters moeilike konflik-situasie in Suid-Afrika aan te bied is blote kaf. 0 Diegene wat Hawke ken, weet ook dat hy geen kaf van enige speler, hoe groot die naam ook al, duld nie. 0 Die uitgetrapte graan en fyn kaf is na die windkant van die vloer gestoot om uitgewan te word. O Fischer se getuienis was die grootste klomp kaf wat die hof in ' $n$ lang tyd gehoor het. 0 Die los koring is met houtgaffels teen die wind gegooi om die koringkorrels en kaf te skei. 0 Oor die jare heen is soveel goeie én slegte Amerikaanse programme uitgesaai, dat die kaf nie meer van die koring geskei kan word nie. Joernaliste het 'n rol te speel om die publiek te help om die kaf van die koring te skei, maar waarom publiseer hulle dan soveel kaf? 0 Hy het nie tussen die kaf en die koring onderskei in sy aanval nie. 0 Wanneer dit by aansprake op nuwe ontwikkelings kom, is die korrels maar dun tussen die kaf gesaai. $0 \mathrm{My}$ dogter is tans besig met studie vir 'n M Sc-graad. 'n Aansienlike deel van haar studiemateriaal is net in Duits (wat sy nie ken nie) beskikbaar. Dit bring mee dat ek lywige stukke uit Duits moet vertaal. Natuurlik doen ek dit graag, maar dit sou soveel beter gewees het as sy dit self kon lees en dadelik die korrels van die kaf kon skei. 0 Dis tyd dat al die kaf wat oor die veiligheidsmagte gepraat word, van die korrels geskei word. $0 \mathrm{Hy}$ kry alle vervelige kafpraters voor stok deur die kaf wat hulle in opgeblase taal kwytraak, in 'n splinternuwe konteks te plaas. 0 Mediabase het gesê hulle het nog "nooit sulke loutere kaf" gehoor nie. 0 Daar word baie kaf gepraat wanneer ouens se tonge by die 19 de putjie los raak. 0 Enigiemand wat hierdie feit nie wil aanvaar nie, loop die gevaar om oor die Hugenote se aankomsgeskiedenis kaf te praat of te skryf, soos reeds meermale gebeur het. 0 Joernaliste het ' $n$ rol te speel om die publiek te help om die kaf van die koring te skei, maar waarom publiseer hulle dan soveel van die kaf 0 As daar deur al die kaf na die kern van die saak heengesny word, blyk dit dat die sittende president met 'n paar hoofsaaklik prosessuele beperkings al elf lede van die hof sal kan aanstel. 0 "Ek daag mense uit wat volhou met diè spul kaf om in die openbaar die teendeel te beswys," het mnr. Peter Hendrickse gesê. 0 Saans het ons die stoppels kaf uit ons hare geskud. 0 Want kyk, die Chinese vat self nie kaf van liberale kabouters nie. 0 Hoe sal Suid-Afrika teen 2000 lyk? Soos 'n immergroen boom? Of soos kaf wat in die wind wegwaai? Dit sal baie afhang van hoe ernstig gelowiges in Suid-Afrika hul godsdiens gaan neem.

With acknowledgements to Jana Luther

\section{Conclusion}

There is an important place in Afrikaans lexicography for a specialized collocation and phrase dictionary from which both mother-tongue speakers and advanced learners of Afrikaans can benefit. This dictionary should be compiled according to theoretical criteria, but the specific needs and skills of the target users should be taken into account.

\section{Bibliography}

Benson, M., E. Benson and R. Ilson. 1986. The BBI Combinatory Dictionary of English. Amsterdam: John Benjamins. 
Benson, M. 1989. The Structure of the Collocational Dictionary. International Journal of Lexicography 2: 1-14.

Benson, M. 1990. Collocations and General-purpose Dictionaries. International Journal of Lexicography 3: 23-34.

Carstens, A. 1992. Kollokasies: vrye verbindings of lekseme? Suid-Afrikaanse Tydskrif vir Taalkunde 10: $1-11$

Church, K. and P. Hanks. 1990. Word Association Norms, Mutual Information, and Lexicography. Computational Linguistics 16: 22-29.

Church, K., W. Gale, P. Hanks and D. Hindle. 1991. Using Statistics in Lexical Analysis. Zernik, Uri (Ed.). 1991. Lexical Acquisition: Exploiting On-Line Resources to Build a Lexicon: 115-164. Hillsdale, New Jersey: Lawrence Erlbaum Associates.

Cowie, A.P. 1981. The Treatment of Collocations and Idioms in Leamers' Dictionaries. Applied Linguistics 11: 223-235.

Firth, J.R. 1957. Modes of Meaning. Papers in Linguistics, 1934-1951: 190-215.

Gouws, R.H. 1989. Leksikografie. Pretoria/Kaapstad: Academica.

Greenbaum, S. 1974/1988. Some Verb-intensifier Collocations in American and British English. Greenbaum, S. 1988. Good English and the Grammarian: 113-124. London: Longman.

Halliday, M.A.K. and R. Hasan. 1976. Cohesion in English. London: Longman.

Hausmann, F.J. 1979. Un dictionnaire des collocations est-il possible? Travaux de linguistique et de littérature 17: 187-195.

Hausmann, F.J. 1984. Wortschatzlemen ist Kollokationslemen. Praxis des neusprachlichen Unterrichts 31: 395-406.

Hansmann, F.J. 1985. Kollokationen im deutschen Wörterbuch. Bergenholtz, H. and J. Mugdan (Eỏs.). 1985. Grammatik im Wörterbuch: 118-129. Tübingen: Max Niemeyer.

Hausmann, F.J., O. Reichmann, H.E. Wiegand and L. Zgusta (Eds.). 1989. Wörterbücher/Dictionaries/Dictionnaires. Berlin/New York: Walter de Gruyter.

Herbst, T. 1996. What are Collocations: Sandy Beaches or False Teeth? English Studies 4: 379-393.

Knowles, F.E. 1997. Collocability in Languages for Special Purposes (LSPs): Some Preliminaries. Lexikos 7: 70-93.

Lombard, F.J. 1992. Voorbeeldmateriaal in woordeboeke. Lexikos 2: 148-164.

Mel'cuk, I.A. and A. Žolkovskij. 1984. Explanatory Combinatorial Dictionary of Modern Russian. Vienna: Wiener Slawistischer Almanach.

Odendal, F.F. 1994. Verklarende Handwoordeboek van die Afrikaanse Taal (HAT). Midrand: Perskor. Sinclair, J. (Ed.). 1987. Collins COBUILD English Language Dictionary. London: Collins.

Smadja, F. 1993. Retrieving Collocations From Text: Xtract. Computational Linguistics 19: 143-177.

Svensén, B. 1993. Practical Lexicography. Oxford/New York: Oxford University Press. 